\title{
Moulds Menaces in Flood-Ravaged Homes: A Case Study of Dar Es Salaam City Tanzania
}

\author{
Donatha Damian Tibuhwa \\ University of Dar es Salaam, Tanzania \\ E-mail: dtibuhwa@yahoo.co.uk
}

Received: October 6, 2015

Accepted: December 25, 2015

doi:10.5296/jbls.v7i1.8681

URL: http://dx.doi.org/10.5296/jbls.v7i1.8681

\begin{abstract}
Recently, Dar es Salaam city has been experiencing unexpected heavy rains which causes flood in several parts of the city. After the flood, houses are left cloggy, muddy and dumpy which promote the growth of moulds likely to affect returning residents. This work investigated the moulds status in 175 houses affected by the flood. Sampling was done using both Non-Volumetric Air Sampling (NVAS) and Swab Sampling (SS) methods. Macro-micromorphological characters were used for identification of the moulds. The results showed that out of the 175 examined houses $170(97.1 \%)$ were found to have moulds while five houses $(2.9 \%)$ including one control house were free of moulds. Five types of moulds were found dominated by a black spore former Aspegillus niger found in 87 houses $(41.2 \%)$ followed by Penicillium species in 65 houses (37.1\%) and Cladosporium species found in 60 houses (34.3\%). The least group of moulds were the yellow mould Aspergillus flavus and white dermatophyte Trichophyton species each found in 15 houses $(8.6 \%)$. The revealed moulds are well known to be associated with human health problems including production of carcinogenic metabolites, triggering allergic reactions to sensitive individuals, causing keratitis, skin lesions, nail fungus, sinusitis, intrinsic asthma, and pulmonary infections. The study thus suggest an premeditated public awareness on adverse effects that might be caused by moulds, call for the government interventions on thoroughly moulds status establishment and immediate deploy methods of moulds controls before residents returns to their flooded homes wherever such catastrophe occur for the healthy generation.
\end{abstract}

Keywords: Moulds, Flood, Moisture, Dar es Salaam, Swabs

\section{Introduction}

Moulds are microscopic fungi that thrive mostly in places with moist environment. Their growths, or colonies, can start to grow on a damp surface within 24 to 48 hours. They reproduce by spores - tiny, lightweight "seeds"- that travel through the air. Moulds are 
necessary part of the environment; playing vital roles in decomposition and aspects of nutrient recycling. However, they adversely destroy organic materials sometimes useful-in our homes and in our bodies such as wood products, ceiling tiles, cardboard, wallpaper, carpets, drywall, fabric, plants, foods, insulation, decaying leaves and other organic materials. In addition to the damage molds can cause in the flooded homes, they can also cause mild to severe health problems. The effects of human moulds exposure are well documented. It is well established that they cause or exacerbate numerous ailments (Ajello and Hay, 1998; Apostolakos et al., 2001; Burge and Ammann, 1999; Bush and Prochnau, 2004; Croft et al., 2002; Gent et al., 2002; Institute of Medicine, 2004; Kuhn and Ghannoum, 2003; Lin and Williams, 2003; Patterson et al., 1981; Rylander and Lin, 2000; Saini et al., 1998; Woodard et al., 1988; Yang and Johanning, 1996). For example Yang and Johanning (1996) reported effects to health office workers after exposure to aerosols containing Stachybotrys chartarum which correlated very well to the intensity and duration of exposure.

Specific toxins produced by different moulds with their respective health problems are well documented (see Jarvis et al. 1995, Montana et al. 1997). Indoor fungi and their biochemical products are now considered as a national health crisis of epidemic proportions due to the health effects from exposure that most commonly occur by: (i) inhalation (breathing of inhaled spores, spore fragments, or volatile compounds), (ii) absorption or dermal contact (contact with skin), and (iii) ingestion (consuming contaminated materials).

Dar es Salaam city as of recently (2011-2014) experienced unexpected heavy rains which caused flood in several parts of the city. The flood caused many disasters including destructions of infrastructures loss of life and submergence of many houses that left many people homeless and great loss of domestic properties. The houses and buildings that withstood the flood were left cloggy, muddy and dumpy. These building experienced excess moisture, long period of high humidity, high temperature and pools of water in hidden premises. These parameters provide favourable environment for growth of moulds. Returning tenants can be exposed to moulds through inhalation, skin contact or ingestion. Some individuals who are sensitive to allergies and asthmatics may have adverse health problems. The infants, the elderly, the infirm and immune compromised people comprises the groups which are very prone to such effects. This study therefore investigated the moulds status in 175 houses, 174 houses affected by flood and one control house not affected by flood, situated $12 \mathrm{~km}$ apart from the affected area in Dar es Salaam city, Tanzania.

\section{Materials and Methods}

\subsection{Sample Collection}

The methodology of assessing the mould status, involved visiting the site for preliminary survey whereby the Relative Humidity and Temperature were directly and simultaneously recorded on site using weather forecast clock (BRIGHT WEATHER CARE, SCHOLER QUARTZ, SWISS). In order not to miss some fungi present in the air but not easily sedimenting on the detecting media, investigation for moulds status in this study were carried out using a combination of two main methods of air sampling and surface/material sampling as detailed below: 


\subsubsection{Non-Volumetric Air Sampling (NVAS)}

The method utilized Malt Extract Agar (MEA) in ordinary petri dishes by exposing it to the air for 30 minutes in affected houses. This worked by sedimentation or gravity where by moulds spore settled on the media. They were then closed and tightened with Para film followed by incubation, which allowed different moulds spores to grow.

\subsubsection{Swab Sampling (SS)}

This was performed using sterile cotton wool and cotton buds in thin edges. The Swab was first dipped in sterile water and rubbed over sought affected parts especially in hidden high cellulose containing materials such as wooden surfaces viz: cupboards, under the table whereby black moulds had high chances of developing. The swabs were immediately inoculated in the liquid culture media. All the samples were then transported to the laboratory of the Department of Molecular Biology and Biotechnology of the university of Dar es Salaam for isolation and characterization.

For control, same procedures were carried out in one house, which was completely not affected by flood, and it was about $12 \mathrm{~km}$ apart from affected areas.

\subsection{Laboratory Work}

The swab cultures were aseptically transferred to different culture media including the solid plate MEA, by striking method, the process that was done in the laminar flow hood to avoid contaminations. The plates were sealed with the para film and incubated at room temperature for 3 -5 days followed by conventional identification based on colony morphology, general colour, colour changes with age and further clarification on the microscope wherever necessary. Microscopic work involved observing the moulds smear on the compound light microscope at 40 and 100 magnification of a bright field compound Olympus (OLYMPUS BX50 PHASE POL DARKFIELD MICROSCOPE, JAPAN). Microscopic slide preparation involved taking a fungal tissue from well developed colony using a sterilized needle then mount it on the slide with an addition of a drop of water to allow cell disaggregation for easier observation. In some cases where colonies were observed to have many protruding conidia a drop of alcohol was added to wash away the mass of hydrophobic conidia before covering them with cover slip as detailed in Samson et al. (2010). Microscopic examination involved spore formation in both aerial and substrate mycelium, as well as spore general morphology especially shapes and attachment to the stolon.

\section{Results and Discussion}

\subsection{Revealed Moulds Status}

Site visit in 175 houses including one control house situated $12 \mathrm{~km}$ apart from affected area, revealed relatively high temperature and high humidity in the flooded houses. Generally the temperature ranged from minimum value of $29.90^{\circ} \mathrm{C}$, to the highest temperature value of $34.60{ }^{\circ} \mathrm{C}$ while the average value was $32.70^{\circ} \mathrm{C}$. For relative humidity the minimum measure was $56.00 \%$ with average value of $63.57 \%$ while the maximum humidity was recorded in house number 82 with a measure of $81.00 \%$ (Table 1). It was very interesting to note that 


\section{I Macrothink}

high moulds abundance occurrence was associated with high humidity and high temperature. For example the house number 173 used as control in this study and found to have no moulds at all, had a low temperature record of $29.90^{\circ} \mathrm{C}$ and low humidity of $56.00 \%$. Besides, the other four houses that were found to have no moulds in flooded area were similarly noted to have relatively low temperature and humidity as summarized in Table 1.

Out of 175 houses sampled, five including the control house were completely free of moulds, 9 having moulds only in hidden premises while one hundred sixty one were found to have mould in airborne and from hidden premises. The laboratory results found five types of mould dominated by the black moulds Aspergillus niger species that were found in a total of eighty seven houses (49.7\%), followed by Penicillium species a green mould that was found in 65 houses (37.1\%). A brown mould Cladosporium species followed closely and was found in 60 houses (34.3\%), while the yellow mould Aspergillus flavus and white dermatophyte Trichophyton species were each found in hidden premises of fifteen house (Figure 1).
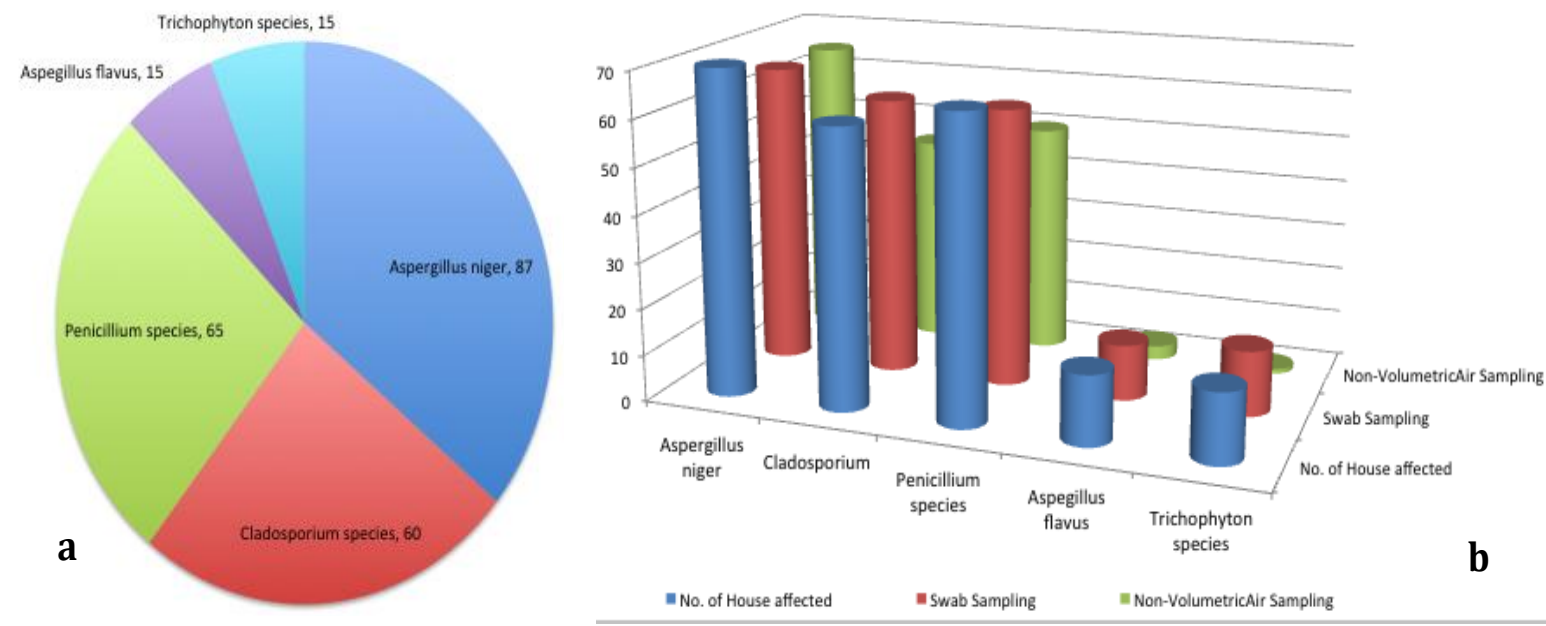

Figure 1. Moulds in different flooded houses (a) black spore former Aspergillus having highest abundance (b) Moulds types in different houses depicted by different sampling methods

Based on the sampling methods it was noted that the swabbing method was more effective compared to the NVAS. This is clearly indicated in Figure $1 \mathrm{~b}$ and Figure 2 whereby SS method presented 166 houses affected with moulds versus 9 houses including the control that showed no mould. On the contrary, the NVAS method presented only 141 houses with moulds versus 34 houses including the control house that had no moulds. In this study SS method revealed high percentage of moulds detection compared to NVAS. Apart from the fact that SS sampling method target hidden premises that were likely to harbor moulds, it also showed higher diversity of the sampled fungi (Figure 1b). It is thus recommended to use both methods, for better results in future studies. 


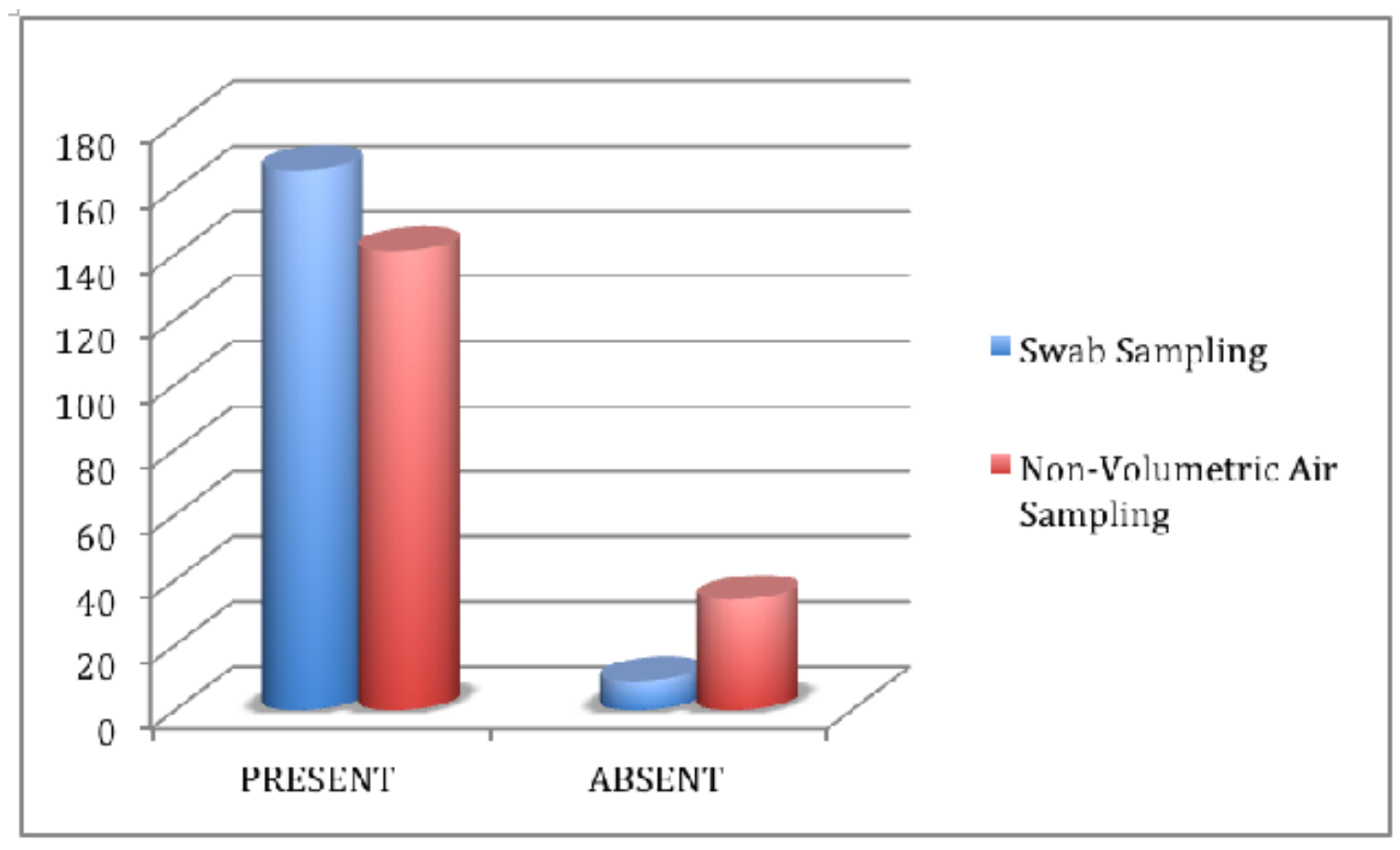

Figure 2. Observed moulds status based on sampling method

Usually after flood moulds are high in numbers and of high diversity because floodwater comes from different sources with lots of contaminants, which favour diversified mould growth. The study therefore, decided to involve culture, sub-culturing to isolate pure colonies (Figure 3) and microscopic characterization in some cases Figure 4 for moulds identification. Many different mould colonies were expected especially in exposed plate sampling method (NVAS). Interestingly, this was not the case since only five types of moulds were found, and the maximum numbers of colonies formed in one plate were twelve. This indicates relative low moulds count and diversity, which is a good indicator for low indoor moulds diversity and abundance in the studied area.

\subsection{Characteristics and General Endangerment Associated With Identified Moulds}

\subsubsection{Aspergillus niger Species Was Found In High Number.}

Microscopically the species is distinguished by its appearance as round single cells like yeast, or made of chains of cells called hyphae. It is the most common Aspergillus species in nature due to its ability to grow on a wide variety of substrates. It is known to cause a "fungal ball" disease, whereby the fungus actively proliferates in the human lung, forming a ball without invading the lung tissue. Diseases caused by Aspergillus are called 'aspergillosis'. The severity of aspergillosis depends on the specific species causing the diseases as well as the state of the immune system of the person. It is well linked to hearing problems including tinnitus and hearing loss. 


\section{Macrothink}

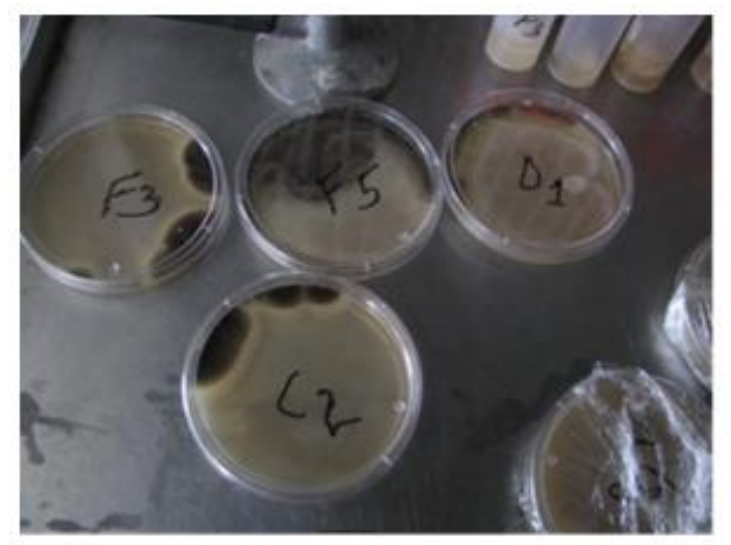

a

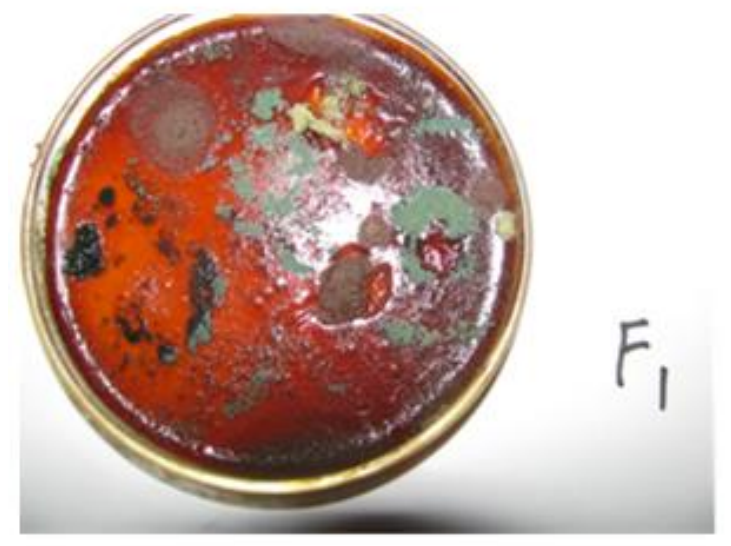

c

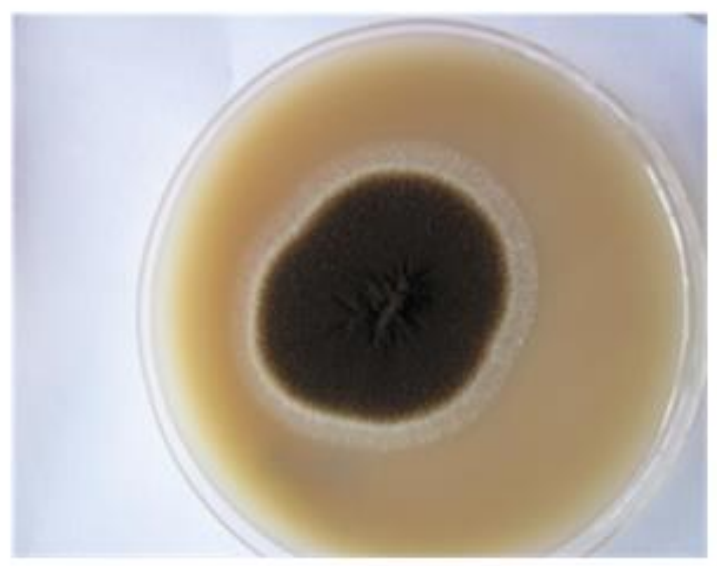

e

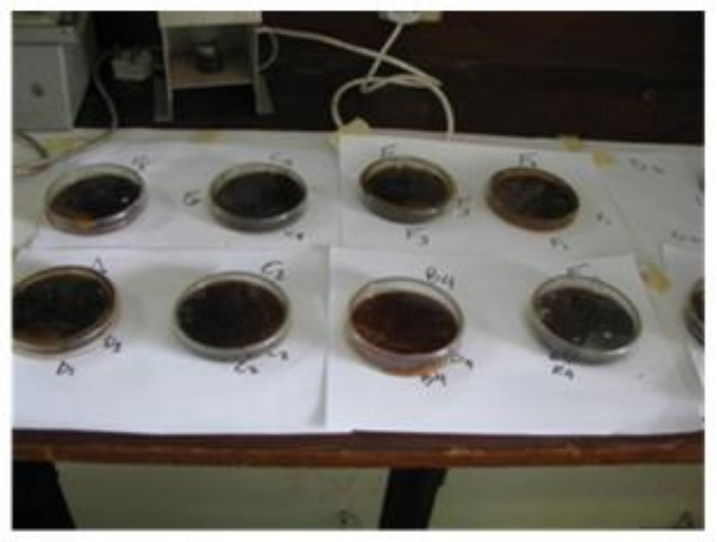

b

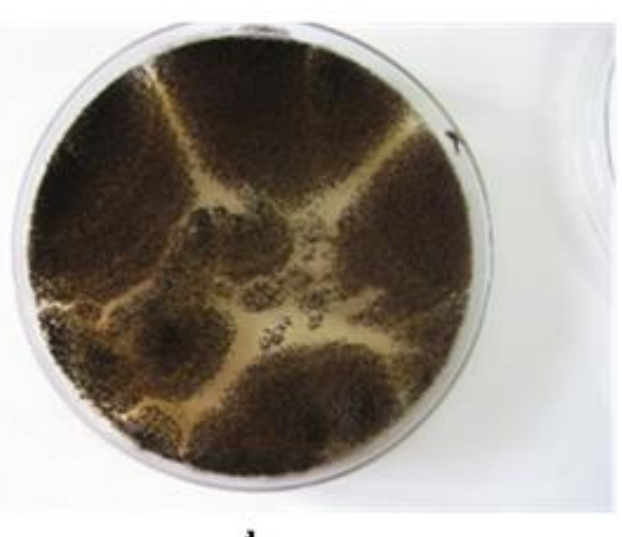

d

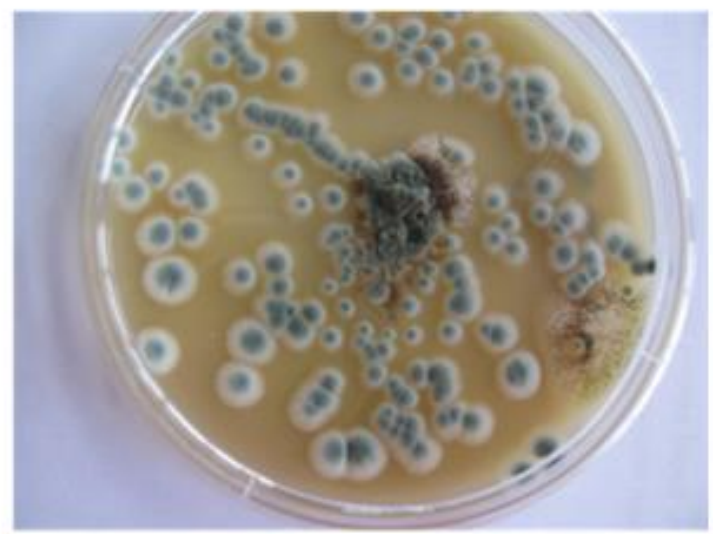

f

Figure 3. Some observed moulds colonies in different houses; (a) Aspergillus species obtained by swabbing method, (b) Plates incubated at room temperature, (c) Mixed colonies of all found moulds, brown, black, green, yellow and white moulds (d) Mixed colonies brown- Clasosporium, green- Penicillium; (e) Pure colony of Cladosporium obtained by sub culturing (f) Penicillium mixed with Cladosporium 


\section{Macrothink}
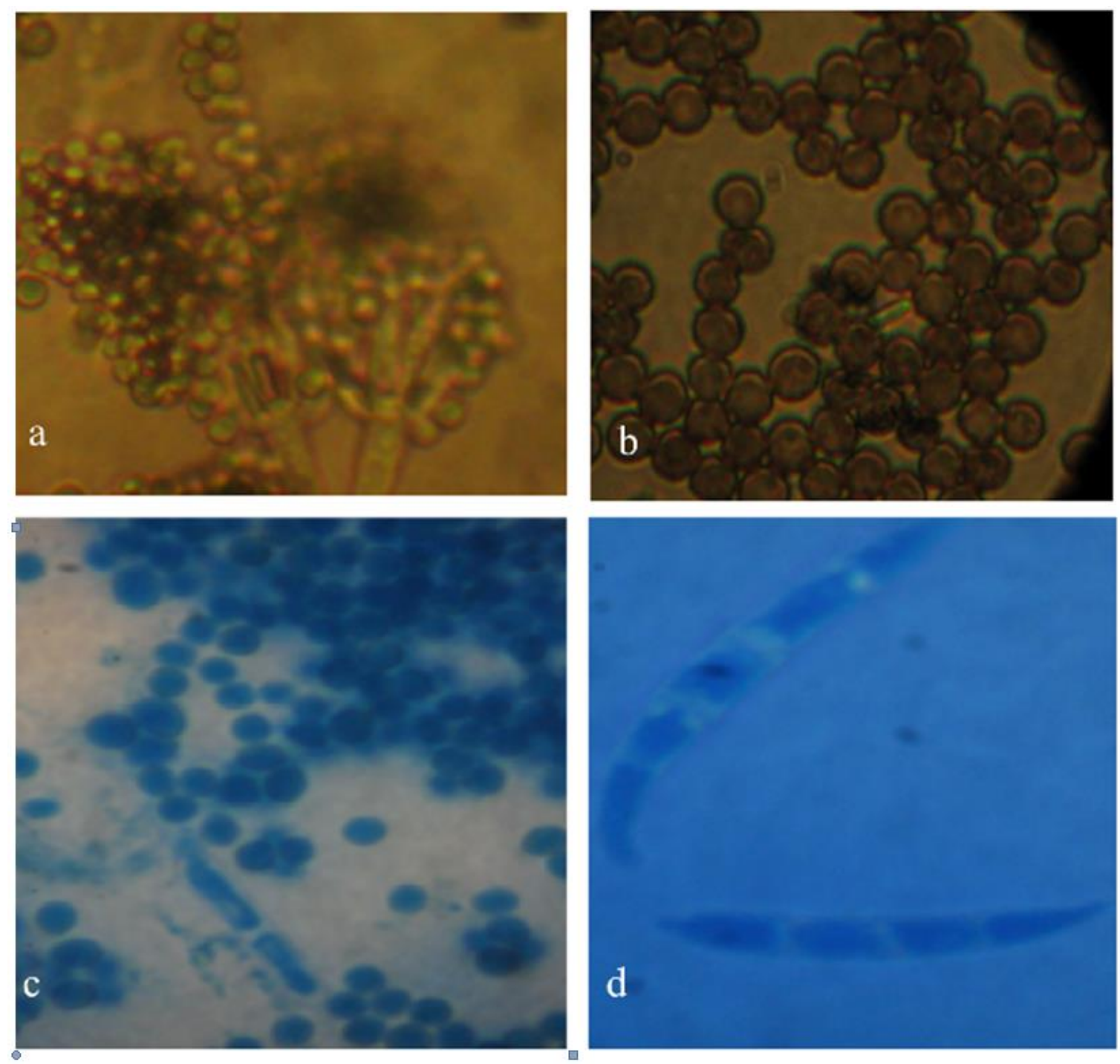

Figure 4. Some microscopic characteristics of determined moulds in different houses sampled from Ilala and Kinondoni districts (a) Penicillium -bloom like spores, (b) Aspergillus niger spores (c \& d) Trichophyton species

3.2.2 Aspergillus flavus colonies are characterized by rapid growth, yellowish-green, consisting of a dense felt of conidiophores or mature vesicles bearing phialides over their entire surface. Texture is woolly to cottony to somewhat granular. Aspergillus flavus is well known for producing the most potent naturally occurring carcinogen, aflatoxin B1 (Davis et al., 1966; Frisvad and Thrane, 2002) although it is argued by other researchers that it is missing when the fungus grow in building materials (Nielsen, 2002).

3.2.3 Cladosporium species colony are characteristically distinguished by their rather slow growing, mostly olivaceous-brown to blackish brown but also sometimes grey, buff or brown, often becoming velvety to powdery texture due to the production of abundant conidia. Species of Cladosporium are not human pathogens except in some cases of immune-compromised patients. However, they are well known for triggering allergic reactions to sensitive individuals, causing keratitis, skin lesions, nail fungus, sinusitis, 
intrinsic asthma, and pulmonary infections. Cladosporium species multiply abundantly in houses with poor ventilation and those built in low damp areas. Since they are airborne moulds, eradicating them will mainly base on treating the environment by lowering the humidity inside houses via keeping window and door wide open to allow air circulation.

3.2.4 Penicillium species are microscopically distinguished by chains of conidia that resemble a broom growing on a highly branched network of multinucleate, septate, usually colorless hyphae. Penicillium species rarely causes humans infections and the resulting disease is known generically as 'penicilliosis'. However, different Penicillium species are well known for their ability of producing mycotoxins. For example, Ochratoxin A, Verrucosidin, neurotoxity and Penicillic toxins causing different health problems which cause cancer and nephrotoxic which causes kidney and liver damage. Some species also cause hypersensitivity pneumonitis, asthma, and allergic alveolitis in susceptible individuals.

3.2.5 Trichophyton species are portrayed by the presence of both smooth-walled macro- and microconidia. Macroconidia are typically thin- or thick-walled, shaped clavate to fusiform and born laterally on the hyphae or short pedicels (Figure 4). While macroconidia are few or absent in many species, microconidia are spherical, pyriform to clavate or of irregular shape, and range from $2-3$ by $2-4 \mu \mathrm{m}$ in size. The genus comprises parasitic members that cause tinea, including athlete's foot, ringworm, jock itch, and similar infections of the nail, beard, skin and scalp.

One week site re visit sampling, showed relative humidity in the flooded houses gradually going down from $81 \%$ noted during the first survey to the normal range of 50-68 \% in Dar es Salaam locality. Typical moulds odor 'earthy or musty smell' were still persisting and some of the stuffs in different houses were unusually found with lots of green moulds growing on them, which showed that they were brought back inside houses before they dry completely. Some dangerous moulds species such as Stachybotrys species which are associated with the development of idiopathic pulmonary hemosiderosis (IPH) in infants (Vesper and Vesper, 2002) are slow growers, and their spores are formed in sticky mass or mucilage which entangle them thus make them rarely air borne spores. Nevertheless, the spores get released to the environment when they are disturbed or when the moisture content goes down such that the mucilage dry's out. Although changing the humidity may lead to limited death of the Stachybotrys colonies if present, however, changing the humidity may also induce their heavy sporulation. In fact, the worst scenario for flooded houses returning homeowners is produced by sequential incidents of water damage that promote fungal growth and mycotoxin synthesis, followed by drier conditions that facilitate the liberation of spores and hyphal fragments. This has been well documented by Nielesen et al. (2003) who also noted that fungal growth in buildings starts at a water activity (aw) near 0.8 , but significant quantities of mycotoxins are not produced unless aw reaches 0.95 . Despite the fact that, there are particles far smaller than spores released from moulds colonies growing on building materials in dumpy homes (Gorny et al., 2002) thus making it so difficult to correlate data on viable or total airborne fungi with health problems in mold-contaminated buildings, there is a need for a call for general public edify on the danger which might be associated with early returning residents, who usually comes back immediately in the flooded houses after the water dry out. It is even more 


\section{Macrothink}

Journal of Biology and Life Science

ISSN 2157-6076

2016, Vol. 7, No. 1

dangerous to bring back inside houses materials, which are not well dried as they might harbors, a good number of moulds, which might cause severe health hazards.

Table 1. Mould status by both methods, swabbing and opening plates

\begin{tabular}{|c|c|c|c|c|c|c|c|c|c|c|c|c|c|c|}
\hline \multirow{2}{*}{$\begin{array}{c}\text { HOUSE } \\
\text { No }\end{array}$} & \multicolumn{2}{|c|}{ RESULTS } & \multirow{2}{*}{ HUMIDITY } & \multirow{2}{*}{$\begin{array}{c}\text { TEMPERA } \\
\text { TURE }{ }^{\circ} \mathrm{C}\end{array}$} & \multirow{2}{*}{$\begin{array}{c}\text { HOUSE } \\
\text { No }\end{array}$} & \multicolumn{2}{|c|}{ RESULTS } & \multirow{2}{*}{ HUMIDITY } & \multirow{2}{*}{$\begin{array}{c}\text { TEMPERA } \\
\text { TURE }{ }^{\circ} \mathrm{C}\end{array}$} & \multirow{2}{*}{$\begin{array}{c}\text { HOUSE } \\
\text { No }\end{array}$} & \multicolumn{2}{|c|}{ RESULTS } & \multirow{2}{*}{ HUMIDITY } & \\
\hline & SWARB & $\begin{array}{l}\text { OPENING } \\
\text { PLATE }\end{array}$ & & & & SWARB & \begin{tabular}{|l|} 
OPENING \\
PLATE
\end{tabular} & & & & SWARB & $\begin{array}{l}\text { OPENING } \\
\text { PLATE }\end{array}$ & & \\
\hline 1 & $\begin{array}{l}\text { PRESENT } \\
\end{array}$ & PRESENT & $67.50 \%$ & 33.3 & 59 & $\begin{array}{l}\text { PRESENT } \\
\end{array}$ & PRESENT & $67.00 \%$ & 31.3 & 117 & \begin{tabular}{|l} 
PRESENT \\
\end{tabular} & PRESENT & $59.50 \%$ & 33.6 \\
\hline 2 & PRESENT & \begin{tabular}{|l|} 
PRESENT \\
\end{tabular} & $71.00 \%$ & 33.3 & 60 & \begin{tabular}{|l} 
PRESENT \\
\end{tabular} & PRESENT & $71.00 \%$ & 31.7 & 118 & PRESENT & PRESENT & $58.00 \%$ & 34.6 \\
\hline 3 & ABSENT & PRESENT & $67.50 \%$ & 32.7 & 61 & \begin{tabular}{|l} 
PRESENT \\
\end{tabular} & \begin{tabular}{|l|} 
PRESENT \\
\end{tabular} & $67.50 \%$ & 33.3 & 119 & \begin{tabular}{|l|} 
PRESENT \\
\end{tabular} & \begin{tabular}{|l|} 
PRESENT \\
\end{tabular} & $62.50 \%$ & 34.3 \\
\hline 4 & ABSENT & PRESENT & $61.00 \%$ & 31.6 & 62 & \begin{tabular}{|l} 
PRESENT \\
\end{tabular} & PRESENT & $61.00 \%$ & 32.7 & 120 & \begin{tabular}{|l|} 
PRESENT \\
\end{tabular} & PRESENT & $69.50 \%$ & 34.2 \\
\hline 5 & PRESENT & \begin{tabular}{|l|} 
PRESENT \\
\end{tabular} & $58.00 \%$ & 33.6 & 63 & \begin{tabular}{|l|} 
PRESENT \\
\end{tabular} & PRESENT & $58.00 \%$ & 31.6 & 121 & PRESENT & \begin{tabular}{|l|} 
PRESENT \\
\end{tabular} & $63.50 \%$ & 33.9 \\
\hline 6 & \begin{tabular}{|l} 
PRESENT \\
\end{tabular} & ABSENT & $59.00 \%$ & 34.6 & 64 & \begin{tabular}{|l} 
PRESENT \\
\end{tabular} & \begin{tabular}{|l|} 
PRESENT \\
\end{tabular} & $59.50 \%$ & 31.6 & 122 & \begin{tabular}{|l|} 
PRESENT \\
\end{tabular} & \begin{tabular}{|l|} 
PRESENT \\
\end{tabular} & $67.50 \%$ & 34.1 \\
\hline 7 & PRESENT & $\begin{array}{l}\text { ABSENT } \\
\end{array}$ & $56.00 \%$ & 34.3 & 65 & \begin{tabular}{|l|} 
PRESENT \\
\end{tabular} & PRESENT & $56.00 \%$ & 30.9 & 123 & PRESENT & PRESENT & $61.00 \%$ & 33.4 \\
\hline 8 & PRESENT & ABSENT & $61.50 \%$ & 34.2 & 66 & PRESENT & PRESENT & $62.50 \%$ & 32.1 & 124 & PRESENT & PRESENT & $67.50 \%$ & 33.5 \\
\hline 9 & PRESENT & ABSENT & $62.50 \%$ & 33.9 & 67 & PRESENT & PRESENT & $58.50 \%$ & 31.9 & 125 & PRESENT & PRESENT & $61.00 \%$ & 32.9 \\
\hline 10 & PRESENT & PRESENT & $67.00 \%$ & 34.1 & 68 & PRESENT & PRESENT & $63.50 \%$ & 33.3 & 126 & PRESENT & PRESENT & $58.00 \%$ & 31.7 \\
\hline 11 & PRESENT & PRESENT & $71.00 \%$ & 33.4 & 69 & PRESENT & PRESENT & $70.00 \%$ & 32.7 & 127 & PRESENT & PRESENT & $59.50 \%$ & 34.1 \\
\hline 12 & PRESENT & PRESENT & $67.50 \%$ & 33.5 & 70 & PRESENT & PRESENT & $72.00 \%$ & 31.6 & 128 & PRESENT & PRESENT & $56.00 \%$ & 33.4 \\
\hline 13 & PRESENT & PRESENT & $71.00 \%$ & 32.9 & 71 & PRESENT & PRESENT & $67.50 \%$ & 31.6 & 129 & PRESENT & PRESENT & $62.50 \%$ & 33.5 \\
\hline 14 & PRESENT & PRESENT & $68.00 \%$ & 31.7 & 72 & PRESENT & PRESENT & $65.00 \%$ & 31.6 & 130 & PRESENT & PRESENT & $58.50 \%$ & 32.9 \\
\hline 15 & PRESENT & ABSENT & $59.50 \%$ & 33.6 & 73 & PRESENT & PRESENT & $69.00 \%$ & 31.6 & 131 & PRESENT & PRESENT & $63.50 \%$ & 31.7 \\
\hline 16 & PRESENT & PRESENT & $56.00 \%$ & 34.6 & 74 & PRESENT & PRESENT & $59.50 \%$ & 31.3 & 132 & PRESENT & PRESENT & $58.50 \%$ & 31.6 \\
\hline 17 & PRESENT & PRESENT & $61.00 \%$ & 34.3 & 75 & PRESENT & PRESENT & $68.00 \%$ & 32.1 & 133 & PRESENT & PRESENT & $63.50 \%$ & 32.1 \\
\hline 18 & ABSENT & ABSENT & $57.00 \%$ & 30.2 & 76 & PRESENT & PRESENT & $62.50 \%$ & 31.9 & 134 & PRESENT & PRESENT & $70.00 \%$ & 31.9 \\
\hline 19 & PRESENT & PRESENT & $59.50 \%$ & 33.9 & 77 & PRESENT & PRESENT & $69.50 \%$ & 33.3 & 135 & PRESENT & PRESENT & $72.00 \%$ & 33.3 \\
\hline 20 & PRESENT & PRESENT & $56.00 \%$ & 34.1 & 78 & PRESENT & PRESENT & $63.50 \%$ & 32.7 & 136 & PRESENT & PRESENT & $67.50 \%$ & 32.7 \\
\hline 21 & PRESENT & PRESENT & $62.50 \%$ & 33.4 & 79 & PRESENT & PRESENT & $67.50 \%$ & 32.6 & 137 & PRESENT & PRESENT & $75.00 \%$ & 31.6 \\
\hline 22 & PRESENT & PRESENT & $59.00 \%$ & 33.5 & 80 & $\begin{array}{l}\text { PRESENT } \\
\end{array}$ & PRESENT & $61.00 \%$ & 33.9 & 138 & PRESENT & \begin{tabular}{|l|} 
PRESENT \\
\end{tabular} & $79.00 \%$ & 31.6 \\
\hline 23 & PRESENT & PRESENT & $59.50 \%$ & 32.9 & 81 & PRESENT & PRESENT & $62.00 \%$ & 33.6 & 139 & PRESENT & PRESENT & $79.50 \%$ & 31.6 \\
\hline 24 & PRESENT & PRESENT & $58.00 \%$ & 31.7 & 82 & PRESENT & ABSENT & $81.00 \%$ & 34.6 & 140 & PRESENT & PRESENT & $78.00 \%$ & 32.1 \\
\hline 25 & \begin{tabular}{|l|} 
PRESENT \\
\end{tabular} & PRESENT & $62.50 \%$ & 31.6 & 83 & PRESENT & PRESENT & $67.00 \%$ & 34.3 & 141 & PRESENT & PRESENT & $62.50 \%$ & 31.9 \\
\hline 26 & PRESENT & PRESENT & $58.50 \%$ & 32.1 & 84 & PRESENT & ABSENT & $71.00 \%$ & 34.2 & 142 & PRESENT & PRESENT & $58.00 \%$ & 33.3 \\
\hline 27 & PRESENT & PRESENT & $63.50 \%$ & 31.9 & 85 & $\begin{array}{l}\text { PRESENT } \\
\end{array}$ & PRESENT & $67.50 \%$ & 33.9 & 143 & PRESENT & \begin{tabular}{|l|} 
PRESENT \\
\end{tabular} & $62.50 \%$ & 31.6 \\
\hline 28 & PRESENT & PRESENT & $70.00 \%$ & 33.3 & 86 & PRESENT & ABSENT & $61.00 \%$ & 34.1 & 144 & PRESENT & PRESENT & $78.50 \%$ & 32.8 \\
\hline 29 & PRESENT & PRESENT & $72.00 \%$ & 32.7 & 87 & $\begin{array}{l}\text { PRESENT } \\
\end{array}$ & ABSENT & $58.00 \%$ & 33.4 & 145 & \begin{tabular}{|l|} 
PRESENT \\
\end{tabular} & PRESENT & $56.00 \%$ & 32.9 \\
\hline 20 & PRESENT & \begin{tabular}{|l|} 
PRESENT \\
\end{tabular} & $67.50 \%$ & 31.6 & 88 & PRESENT & PRESENT & $59.50 \%$ & 33.5 & 146 & PRESENT & PRESENT & $71.50 \%$ & 33.3 \\
\hline 31 & PRESENT & PRESENT & $65.00 \%$ & 31.6 & 89 & $\begin{array}{l}\text { PRESENT } \\
\end{array}$ & ABSENT & $56.00 \%$ & 31.9 & 147 & \begin{tabular}{|l|} 
PRESENT \\
\end{tabular} & PRESENT & $58.50 \%$ & 31.6 \\
\hline 32 & PRESENT & \begin{tabular}{|l|} 
PRESENT \\
\end{tabular} & $59.00 \%$ & 31.6 & 90 & PRESENT & ABSENT & $72.50 \%$ & 33.3 & 148 & PRESENT & PRESENT & $79.50 \%$ & 33.9 \\
\hline 33 & \begin{tabular}{|l|} 
PRESENT \\
\end{tabular} & PRESENT & $80.50 \%$ & 33.9 & 91 & \begin{tabular}{|l} 
PRESENT \\
\end{tabular} & ABSENT & $58.50 \%$ & 31.6 & 149 & \begin{tabular}{|l|} 
PRESENT \\
\end{tabular} & PRESENT & $67.00 \%$ & 34.1 \\
\hline 34 & PRESENT & ABSENT & $58.00 \%$ & 34.1 & 92 & \begin{tabular}{|l} 
PRESENT \\
\end{tabular} & ABSENT & $63.50 \%$ & 32.1 & 150 & \begin{tabular}{|l|} 
PRESENT \\
\end{tabular} & PRESENT & $71.00 \%$ & 31.6 \\
\hline 35 & PRESENT & \begin{tabular}{|l|} 
PRESENT \\
\end{tabular} & $62.50 \%$ & 31.6 & 93 & ABSENT & ABSENT & $58.50 \%$ & 31.9 & 151 & PRESENT & PRESENT & $61.00 \%$ & 32.1 \\
\hline 36 & PRESENT & PRESENT & $69.50 \%$ & 32.1 & 94 & $\begin{array}{l}\text { PRESENT } \\
\end{array}$ & ABSENT & $63.50 \%$ & 33.3 & 152 & ABSENT & ABSENT & $58.00 \%$ & 31.9 \\
\hline 37 & ABSENT & ABSENT & $56.50 \%$ & 30.5 & 95 & PRESENT & ABSENT & $58.50 \%$ & 33.6 & 153 & PRESENT & PRESENT & $59.00 \%$ & 33.3 \\
\hline 38 & \begin{tabular}{|l|} 
PRESENT \\
\end{tabular} & PRESENT & $58.50 \%$ & 31.9 & 96 & \begin{tabular}{|l} 
PRESENT \\
\end{tabular} & ABSENT & $63.50 \%$ & 34.6 & 154 & \begin{tabular}{|l|} 
PRESENT \\
\end{tabular} & \begin{tabular}{|l|} 
PRESENT \\
\end{tabular} & $56.00 \%$ & 31.6 \\
\hline 39 & PRESENT & PRESENT & $63.50 \%$ & 33.6 & 97 & PRESENT & ABSENT & $70.00 \%$ & 34.3 & 155 & PRESENT & ABSENT & $61.50 \%$ & 32.1 \\
\hline 40 & $\begin{array}{l}\text { PRESENT } \\
\end{array}$ & PRESENT & $58.50 \%$ & 32.7 & 98 & \begin{tabular}{|l} 
PRESENT \\
\end{tabular} & ABSENT & $72.00 \%$ & 34.2 & 156 & \begin{tabular}{|l|} 
PRESENT \\
\end{tabular} & \begin{tabular}{|l|} 
PRESENT \\
\end{tabular} & $58.50 \%$ & 31.9 \\
\hline 41 & PRESENT & PRESENT & $63.50 \%$ & 31.6 & 99 & PRESENT & ABSENT & $67.50 \%$ & 33.9 & 157 & PRESENT & PRESENT & $64.50 \%$ & 33.6 \\
\hline 42 & PRESENT & PRESENT & $70.00 \%$ & 34.1 & 100 & PRESENT & ABSENT & $65.00 \%$ & 32.9 & 158 & PRESENT & ABSENT & $67.00 \%$ & 32.7 \\
\hline 43 & PRESENT & PRESENT & $72.00 \%$ & 31.6 & 101 & PRESENT & ABSENT & $61.00 \%$ & 31.7 & 159 & PRESENT & PRESENT & $71.00 \%$ & 31.6 \\
\hline 44 & PRESENT & PRESENT & $67.50 \%$ & 32.1 & 102 & PRESENT & PRESENT & $58.00 \%$ & 31.6 & 160 & PRESENT & PRESENT & $67.50 \%$ & 31.6 \\
\hline 45 & PRESENT & PRESENT & $65.00 \%$ & 31.3 & 103 & PRESENT & PRESENT & $59.50 \%$ & 32.1 & 161 & $A B S E N T$ & ABSENT & $58.00 \%$ & 31.1 \\
\hline 46 & PRESENT & PRESENT & $61.00 \%$ & 32.7 & 104 & PRESENT & PRESENT & $61.00 \%$ & 33.6 & 162 & PRESENT & PRESENT & $58.00 \%$ & 31.9 \\
\hline 47 & PRESENT & PRESENT & $58.00 \%$ & 32.9 & 105 & PRESENT & ABSENT & $58.00 \%$ & 34.6 & 163 & PRESENT & PRESENT & $59.50 \%$ & 31.3 \\
\hline 48 & PRESENT & PRESENT & $59.00 \%$ & 33.4 & 106 & PRESENT & PRESENT & $59.50 \%$ & 34.3 & 164 & PRESENT & PRESENT & $56.00 \%$ & 32.7 \\
\hline 49 & PRESENT & PRESENT & $56.00 \%$ & 32.7 & 107 & PRESENT & PRESENT & $56.00 \%$ & 34.2 & 165 & PRESENT & PRESENT & $62.50 \%$ & 31.3 \\
\hline 50 & PRESENT & PRESENT & $61.50 \%$ & 31.6 & 108 & PRESENT & ABSENT & $62.50 \%$ & 32.9 & 166 & PRESENT & PRESENT & $58.50 \%$ & 31.7 \\
\hline 51 & PRESENT & PRESENT & $58.50 \%$ & 33.9 & 109 & PRESENT & PRESENT & $71.00 \%$ & 31.7 & 167 & PRESENT & PRESENT & $63.50 \%$ & 33.3 \\
\hline 52 & PRESENT & PRESENT & $63.50 \%$ & 34.1 & 110 & ABSENT & PRESENT & $67.50 \%$ & 31.6 & 168 & PRESENT & PRESENT & $65.00 \%$ & 32.7 \\
\hline 53 & PRESENT & PRESENT & $58.50 \%$ & 31.6 & 111 & PRESENT & PRESENT & $61.00 \%$ & 32.1 & 169 & PRESENT & ABSENT & $63.50 \%$ & 31.6 \\
\hline 54 & PRESENT & PRESENT & $63.50 \%$ & 32.1 & 112 & PRESENT & PRESENT & $58.00 \%$ & 31.9 & 170 & PRESENT & PRESENT & $58.50 \%$ & 31.6 \\
\hline 55 & PRESENT & PRESENT & $70.00 \%$ & 33.7 & 113 & PRESENT & PRESENT & $59.00 \%$ & 33.3 & 171 & PRESENT & PRESENT & $59.50 \%$ & 30.9 \\
\hline 56 & PRESENT & PRESENT & $72.00 \%$ & 33.5 & 114 & PRESENT & PRESENT & $56.00 \%$ & 32.7 & 172 & PRESENT & PRESENT & $66.00 \%$ & 34.2 \\
\hline 57 & \begin{tabular}{|l|} 
PRESENT \\
\end{tabular} & PRESENT & $67.50 \%$ & 32.7 & 115 & PRESENT & PRESENT & $61.50 \%$ & 31.6 & $173^{*}$ & ABSENT & ABSENT & $56.00 \%$ & 29.9 \\
\hline 58 & PRESENT & PRESENT & $65.00 \%$ & 31.6 & 116 & PRESENT & PRESENT & $58.50 \%$ & 31.6 & 174 & PRESENT & PRESENT & $58.50 \%$ & 34.1 \\
\hline nou & ot afjecte & ed with floc & tuscor & 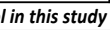 & & & & & & 175 & PRESENT & ABSENT & $63.50 \%$ & 31.9 \\
\hline
\end{tabular}

\section{3 Health and Safety Advisories to Remember When Cleaning Up Mould after Flood}

On cleaning precautions has to be taken on black mold that are growing on sheetrock. There is a possibility that it may be Stachybotrys chartarum. This kind of mold produces a toxin, which has been associated with severe health problems in humans (Kuhn 2003). During 
cleaning it is also important to minimize your exposure by wearing gloves and a mask or a respirator to filter out mold spores as well as splash goggles to help protect your eyes, long sleeves, long pants and sturdy shoes. Be vigilant in looking for a whitish or yellowish cotton candy-like mold as they might be Fusarium species, which like the black mold also produces a toxin that is associated with adverse health problems in humans. It was of concern to note some black spore formers in this study including identified Aspergillus species (Figure 3). It is thus very important to be cautious with possibility of moulds development in flooded homes in order to salvage the adverse effects to the returning residents.

\subsection{Some Methods to Be Deployed in Controlling Moulds in Flooded Houses}

It is well known that moulds growth is promoted by high moisture content especially when water activity (aw) is near 0.8 and subsequent mycotoxins production aw 0.95 (Nielesen et al. 2003). It is thus very important to control the moisture content in flooded houses in order to prevent moulds growth. This can be attained by several methods including drying all wet materials very quickly and if possible, use air conditioning in dry mode or heat with fans and dehumidifier, remove wet carpeting right away and discard them if you can not clean or disinfect and dry them quickly. Clean all surfaces such as hard plastic, concrete, glass, metal and solid wood Apply some mild detergent such as nonphosphate detergents, alcohols and hydrogen peroxide repeatedly at least for seven days to ensure that you kill all re-growing new colonies since disinfectants kill molds but do not prevent re-growth.

All in all returning residents need to remain on mold alert continue looking for signs of moisture or new mold growth since some material might not be dry enough during the cleaning and if the mold returns, repeat the cleaning. Moulds thrive needs a moist, wet, or damp environment. By maintaining the houses clean and dry will automatically prohibit mould growth. Special effort should be done to ensure no leaky or broken pipes, and ensure complete dryness before cosmetic ventures to repair broken parts. After flood water is superficially dried, door and windows should be kept wide open most of the time to allow normal drying by wind to continue and improving the air circulation in the houses.

\section{Conclusion}

Flooded houses is accompanied with moulds thrive which needs a moist, wet, or damp environment thus, maintaining the houses clean and dry through keeping the door and windows wide-open most of the time to allow normal drying by wind and improved air circulation in the houses will automatically prohibit moulds growth. Wherever possible, clean the house floor, hidden corners such as cupboard table and chairs using less corrosive disinfectants such as alcohols and hydrogen peroxide regularly for three months to ensure stopping of germination of more moulds spores. Special effort should be done to ensure no leaky or broken pipes, and ensure complete dryness before cosmetic ventures to repair broken parts. All in all the study suggest an premeditated public awareness on adverse effects that might be caused by moulds, call for the government interventions on thoroughly moulds status establishment and immediate deploy methods of moulds controls before residents returns to their flooded homes wherever such catastrophe occur for the healthy generation. 


\section{Acknowledgements}

The Department of Molecular Biology and Biotechnology University of Dar es Salaam is acknowledged for providing venue and facilities during the study. The author is also indebted to Mr. Charles Kweyunga of Botany Department University of Dar salaam for helping with the sample collection and laboratory work.

\section{Reference}

Ajello, L., \& R. Hay (1998). Topley \& Wilson's Microbiology and Microbial Infections, 9th ed., Vol. 4: Medical Mycology, Edward Arnold, New York. PMCid:PMC104916

Apostolakos, M. J., H. Rossmoore, W. S. Beckett (2001). Hypersensitivity pneumonitis from ordinary residential exposures. Environmental Health Perspectives, 109, 979-981. http://dx.doi.org/10.1289/ehp.01109979

Burge, H. A., \& H. A. Ammann (1999). Fungal Toxins and b-(1-3)-D-Glucans. In: Bioaerosols Assessment and Control. (J. Machler, Ed.). American Conference of Industrial Hygienists, Cincinnati, $\mathrm{OH}$.

Bush, R. K., \& J. J. Prochnau (2004). Alternaria-induced asthma. J Allergy Clin Immunol. 113, 227-34. http://dx.doi.org/10.1016/j.jaci.2003.11.023

Croft, W. A., B. M. Jastromski, A. L. Croft, \& H. A. Peters (2002). Clinical confirmation of trichothecene mycotoxicosis in patient urine. J. Environ. Biol. 23, 301-320. PMid:12597576

Davis, N. D., Diener, U. L., \& D. W. Eldridge (1966). Production of aflatoxins B1 and G1 by Aspergillus flavus on a semisynthetic medium. Appl. Microbiol. 14, 378. PMid:5970823

Frisvad, J. C., Thrane, U., \& O. Filtenborg (1998). Role and use of secondary metabolites in fungal taxonomy. In: Frisvad, J.C., Bridge, P.D., Arora, D.K. (Eds.), In Chemical fungal taxonomy. Marcel Dekker, New York, pp. 289-319.

Gent J. F., P. Ren, K. Belanger, E. Triche, M. B. Bracken, T. R. Holford, \& B. P. Leaderer (2002). Levels of household mold associated with respiratory symptoms in the first year of life in a cohort at risk for asthma. Environ Health Perspect. 110, A781-6. http://dx.doi.org/10.1289/ehp.021100781.

Gorny, R. L., Reponen, T., Willeke, K., Schmechel, D., Robine, E., Boissier, M. \&, S. A. Grinshpun (2002). Fungal fragments as indoor air biocontaminants. Appl. Environ. Microbiol. 68, 3522-3531. http://dx.doi.org/10.1128/AEM.68.7.3522-3531.2002

Jarvis, B. B., Zhou, Y., Jiang, J., Wang, S., Sorenson, W. G., Hintikka, E.-L., Nikulin, M., Parikka, P., Etzel, R. A., \& D. G. Dearborn (1996). Toxigenic moulds in water-damaged buildings: dechlorogriseofulvins from Memnoniella echinata. J. Nat. Prod. 59, 553-554. http://dx.doi.org/10.1021/np960395t

Kuhn, D. M., \& M. A. Ghannoum (2003). Indoor mold, toxigenic fungi, and Stachybotrys chartarum: infectious disease perspective. Clin Microbiol Rev. 16, 144-172. http://dx.doi.org/10.1128/CMR.16.1.144-172.2003 


\section{1) Macrothink}

Journal of Biology and Life Science ISSN 2157-6076 2016, Vol. 7, No. 1

Lin, R. Y., \& K. D. Williams (2003). Hypersensitivity to molds in New York City in adults who have asthma. Allergy Asthma Proc. 24, 13-8. PMid:12635573

Institute of Medicine (2004). Damp Indoor Spaces and Health. National Academies Press, Washington D. C. Montana, E., Etzel, R. A., Dearborn, D. G., Sorenson, W.G., R. Hill (1995). Acute pulmonary hemorrhage in infancy associated with Stachybotrys atra-Cleveland Ohio, 1993-1995. Am. J. Epidemiol. 141, S83.

Nielsen, K. F., Nielsen, P. A., \& G. Holm (2000). Growth of moulds on building materials under different humidities. In: Sepp€anen, O., S€ateri, J. (Eds.), Proceedings of Healthy Buildings 2000, August 6-10, 2000, Espoo, Finland, SYI Indoor Air Information Oy, Helsinki, 283-288. PMid:10895992

Patterson, R., J. N. Fink, W. B. Miles, J. E. Basich, D. B. Schleuter, D. G. Tinkelman, \& M. Roberts (1981). Hypersensitivity lung disease presumptively due to Cephalosporium in homes contaminated by sewage flooding or by humidifier water. J. Allergy Clin Immunol. 68, 128-32. http://dx.doi.org/10.1016/0091-6749(81)90171-8

Rylander, R., \& R. H. Lin (2000). (1®3)-Beta-D-glucan - relationship to indoor air-related symptoms, allergy and asthma. Toxicology 152, 47-52. http://dx.doi.org/10.1016/S0300-483X(00)00291-2

Saini, S. K., S. R. Boas, A. Jerath, M. Roberts, \& P. A. Greenberger (1998). Allergic bronchopulmonary mycosis to Fusarium vasinfectum in a child. Ann Allergy Asthma Immunol. 80, 377-380. http://dx.doi.org/10.1016/S1081-1206(10)62986-9

Woodard, E. D., B. Friedlander, R. J. Lesher, W. Font, R. Kinsey, \& F. T. Hearne (1988). Outbreak of hypersensitivity pneumonitis in an industrial setting. JAMA. 259, 1965-1969 http://dx.doi.org/10.1001/jama.259.13.1965

Yang C., \& E. Johanning (1996). Airborne Fungi and Mycotoxins, In: Manual of Environmental Microbiology, C. Hurst (Editor in Chief), ASM Press, Washington, D.C.

Samason RA, Houbraken J, Thrane U, Frisvad J.C. \& B. Andersen (2010). Food and Indoor Fungi. CBS-KNAW Fungal Biodiversity Centre. 390pp.

Vesper, S. J., \& M. J. Vesper (2002). Stachylysin may be a cause of hemorrhaging in humans exposed to Stachybotrys chartarum. Infec. Immun. 70, 2065-2069. http://dx.doi.org/10.1128/IAI.70.4.2065-2069.2002

\section{Copyright Disclaimer}

Copyright for this article is retained by the author(s), with first publication rights granted to the journal.

This is an open-access article distributed under the terms and conditions of the Creative Commons Attribution license (http://creativecommons.org/licenses/by/3.0/). 